\title{
Effects of industrial processing methods on camel skimmed milk properties
}

\section{Article}

\section{Accepted Version}

Creative Commons: Attribution-Noncommercial-No Derivative Works 4.0

Omar, A., Harbourne, N. and Oruna-Concha, M. J. (2018) Effects of industrial processing methods on camel skimmed milk properties. International Dairy Journal, 84. pp. 15-22. ISSN 0958-6946 doi: https://doi.org/10.1016/j.idairyj.2018.03.011 Available at https://centaur.reading.ac.uk/76703/

It is advisable to refer to the publisher's version if you intend to cite from the work. See Guidance on citing.

To link to this article DOI: http://dx.doi.org/10.1016/j.idairyj.2018.03.011

Publisher: Elsevier

All outputs in CentAUR are protected by Intellectual Property Rights law, including copyright law. Copyright and IPR is retained by the creators or other copyright holders. Terms and conditions for use of this material are defined in the End User Agreement.

\section{www.reading.ac.uk/centaur}

\section{CentAUR}

Central Archive at the University of Reading 
Reading's research outputs online 


\section{Accepted Manuscript}

Effects of industrial processing methods on camel skimmed milk properties

Adel Omar, Niamh Harbourne, Maria J. Oruna-Concha

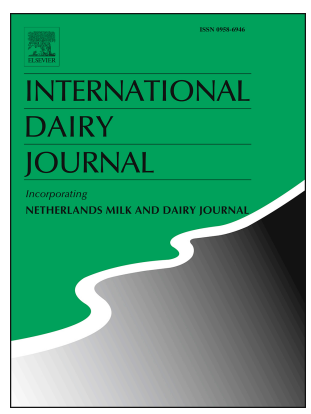

PII: S0958-6946(18)30076-1

DOI: $\quad$ 10.1016/j.idairyj.2018.03.011

Reference: INDA 4296

To appear in: International Dairy Journal

Received Date: 25 October 2017

Revised Date: 24 March 2018

Accepted Date: 26 March 2018

Please cite this article as: Omar, A., Harbourne, N., Oruna-Concha, M.J., Effects of industrial processing methods on camel skimmed milk properties, International Dairy Journal (2018), doi: 10.1016/ j.idairyj.2018.03.011.

This is a PDF file of an unedited manuscript that has been accepted for publication. As a service to our customers we are providing this early version of the manuscript. The manuscript will undergo copyediting, typesetting, and review of the resulting proof before it is published in its final form. Please note that during the production process errors may be discovered which could affect the content, and all legal disclaimers that apply to the journal pertain. 


\section{Effects of industrial processing methods on camel skimmed milk properties}

Adel Omar ${ }^{\mathrm{a} *}$, Niamh Harbourne ${ }^{\mathrm{b}}$, Maria J. Oruna-Concha ${ }^{\mathrm{a}}$

${ }^{a}$ Department of Food and Nutritional Sciences, University of Reading, Reading, United Kingdom

${ }^{b}$ UCD Institute of Food and Health, School of Agriculture and Food Science, University College Dublin, Belfield, Dublin, Ireland

*Corresponding author. Tel.:

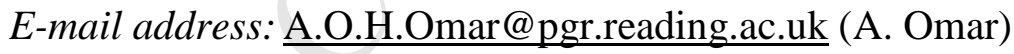




\section{ABSTRACT}

Effects of pasteurisation (high-temperature-short-time; HTST), ultra-high-temperature (UHT), and high-pressure (HP) treatments on some physical and chemical properties of camel milk $(\mathrm{CM})$, including whey protein denaturation, colour change, casein micelle size, and rennet coagulation time (RCT), was investigated. UHT treatment caused the biggest colour change and highest whey protein denaturation in CM; in contrast, the effects of HP treatments on these properties were considerably less. Casein micelle size decreased after all treatments. The RCT of CM was significantly delayed and coagulum strength $\left(G^{\prime}\right)$ decreased after HTST. HP treatment at 200 and $400 \mathrm{MPa}$ increased the RCT of CM and the $G^{\prime}$ value was the highest after treatment at $200 \mathrm{MPa}$. Processing at 600 and $800 \mathrm{MPa}$ inhibited coagulation of CM. The effects of both thermal and non-thermal treatments on many constituents and properties of CM were different from those on constituents and properties of bovine milk. 


\section{Introduction}

Camels (Camelus dromedarius) have traditionally been the primary source of milk in many countries in Africa and Asia, particularly during dry seasons because camels are well adapted to harsh conditions in arid and semi-arid regions. Camel milk (CM) is mainly consumed in its raw state or as a fermented milk with varying degrees of sourness (Alhaj \& AlKanhal, 2010).

Heat treatments, such as high-temperature, short-time pasteurisation (HTST) and ultra-high-temperature (UHT) are typically applied to milk to ensure better microbiological quality and increase its shelf life for human consumption. It is well known that these treatments influence the physical and chemical properties of bovine milk (McSweeney \& Fox, 2013).

Recently, there has been an increase in consumer demand for low-fat dairy products, including skimmed milk. In addition, $\mathrm{CM}$ is becoming more popular due to its potential beneficial effects on human health such as anti-cancer, hypo-allergenic and anti-diabetic effects (Kaskous, 2016). It also has lower cholesterol, lower sugar, higher minerals (sodium, potassium, iron, copper, zinc and magnesium) and vitamin $\mathrm{C}$ than bovine milk (Jilo \& Tegegne, 2016). Therefore, investigating the effects of heat treatments on skimmed CM is of great technological importance, as thermal treatment is an important step involved in the processing of milk and milk products. Nevertheless, very few studies have focused on the influence of heat treatments on CM and the results from published studies are contradictory and mostly in relation to whey proteins.

Farah and Atkins, (1992) and Sagar, Mehta, Wadhwani, Darji, \& Aparnathi (2016) reported that skimmed and whole CM had poor heat stability at high temperatures (100-140 $\left.{ }^{\circ} \mathrm{C}\right)$ compared with bovine and buffalo milk. Similarly, Alhaj, Metwalli, and Ismail (2011) 
showed that heat treatment $\left(121^{\circ} \mathrm{C}\right.$ for $\left.15 \mathrm{~min}\right)$ of whole $\mathrm{CM}$ at its natural $\mathrm{pH}$ resulted in partial or complete protein precipitation indicating poor heat-stability; however, they demonstrated that the heat stability could be improved by increasing the milk $\mathrm{pH}$ to $7.0-7.2$ and addition of $\kappa$-casein, EDTA or sodium phosphate. Furthermore, CM whey proteins were also reported to be more sensitive to heat treatments, with denaturation rates faster than those of bovine milk (Felfoul, Lopez, Gaucheron, Attia, \& Ayadi, 2015a). Benabdelkamel et al. (2017) indicated that heat treatment of $\mathrm{CM}$ whey at $98^{\circ} \mathrm{C}$ for $60 \mathrm{~min}$ caused a significant denaturation of camel $\alpha$-lactalbumin ( $\alpha$-la), lactoferrin (LF), and serum albumin (SA). Similarly, Felfoul, Jardin, Gaucheron, Attia, and Ayadi (2017) found that whey proteins in skimmed camel and bovine milk were significantly affected by heat treatment at $80{ }^{\circ} \mathrm{C}$ for 60 min, whereas casein fractions remained intact under the same heat conditions for both types of milk.

In contrast, several studies reported that $\mathrm{CM}$ whey proteins were more heat stable than bovine whey proteins. Elagamy (2000) reported that camel whey proteins were considerably more heat resistant than their counterparts in bovine milk after pasteurisation at $65,75,85$, and $100{ }^{\circ} \mathrm{C}$ for 10,20 , and $30 \mathrm{~min}$. Furthermore, camel $\alpha$-la was found to be more heat stable than bovine $\alpha$-la during pasteurisation due to the secondary structure of camel $\alpha$-la being conserved better than that of bovine $\alpha$-la during heat denaturation (Atri et al., 2010). Laleye, Jobe, and Wasesa (2008) reported that there was no significant difference in the heat stability of liquid whey separated from camel or bovine milk during pasteurisation at 60, 70, 80, 90, and $100{ }^{\circ} \mathrm{C}$.

Preliminary work on dried whey in the same study suggests that camel whey proteins were slightly more sensitive to heat denaturation than bovine whey. Factors including stage of lactation, camel breeds, feeding conditions and geographical location might be responsible for the conflicting results reported regarding the heat stability of whey proteins in CM (Alhaj 
\& AlKanhal, 2010). Levieux, Levieux, El-Hatmi, and Rigaudie (2006) found that whey proteins in early $\mathrm{CM}$ (the first week lactation) were more sensitive to heat treatment than those in $\mathrm{CM}$ after three months. This difference in the heat denaturation was attributed to the high content of $\mathrm{IgG}, 12.6 \mathrm{mg} \mathrm{mL}^{-1}$ in early $\mathrm{CM}$ compared with $0.5 \mathrm{mg} \mathrm{mL}^{-1}$ in milk from camels during the later stages of lactation.

High-pressure (HP) processing is an alternative preservation method to traditional heat treatments. Previous research has shown that HP processing can cause changes in milk including upsetting the mineral balance of the milk, denaturing whey proteins, inducing aggregation or disruption of casein micelles, changing the activity of native milk enzymes, changing the colour of the milk and altering the rennet coagulation properties (Huppertz, Smiddy, Upadhyay, \& Kelly, 2006; López-Fandiño, 2006; Trujillo, Capellas, Saldo, Gervilla, \& Guamis, 2002).

The majority of studies focusing on the effect of HP on milk have been conducted using bovine, buffalo, ewe, or ovine milk (Gervilla, Ferragut, \& Guamis, 2001; Huppertz et al., 2005; Moatsou et al., 2008a,b). However, the effects of HP on the physicochemical and functional properties of CM have not been studied to date. Therefore, the aim of this study was to investigate the effects of commonly used food-processing methods (HTST, UHT, and HP) on some components and properties of skimmed CM, including whey protein denaturation, casein micelle size, appearance, and rennet coagulation properties. In addition, the results obtained were compared with those from bovine milk.

\section{Materials and methods}

\subsection{Chemicals and reagents}


Pure camel chymosin (FAR-M ${ }^{\circledR}$ ) available in powder form (CAS: 9001-98-3) suitable for both camel and bovine milk was obtained from Chr. Hansen Laboratories A/S (Copenhagen, Denmark). Sodium dihydrogen orthophosphate monohydrate $\left(\mathrm{NaH}_{2} \mathrm{PO}_{4} \cdot \mathrm{H}_{2} \mathrm{O}\right)$ was obtained from BDH Laboratory supplies (Poole, Dorset, UK). Protein standards (from bovine milk) $\beta$-lactoglobulin $(\beta-\lg )$ (purity $\geq 90 \%)$, serum albumin $($ BSA) $(\geq 98 \%), \alpha-$ lactalbumin ( $\alpha$-la) ( $\geq 85 \%$ ), and lactoferrin (LF) ( $\geq 85 \%$ ) were obtained from Sigma-Aldrich (Poole, Dorset, UK). Propanediol oil was obtained from Sigma-Aldrich. All chemicals were high performance liquid chromatography grade (Sigma-Aldrich) and used without any further purification.

\subsection{Milk samples}

Forty litres ( 80 bottles, $500 \mathrm{~mL}$ in size) of commercially available raw dromedary camel milk produced by Kamelenmelkerij Smits (Cromvoirt, The Netherlands) were purchased from the UK Camel Milk Ltd (Bolton, Lancashire, UK) in January (winter season). The CM was frozen and directly transported using ice boxes. For comparison, raw bovine milk of Holstein Friesian dairy cows was obtained from the University of Reading's farm. Upon arrival, the frozen milk samples were kept at $-18{ }^{\circ} \mathrm{C}$ until further treatment. Prior to processing, milk samples were defrosted at $4{ }^{\circ} \mathrm{C}$ overnight $(13 \mathrm{~h})$ and then kept at room temperature $\left(23^{\circ} \mathrm{C}\right)$ for $30 \mathrm{~min}$ and gently mixed. The milk samples were then skimmed and directly subjected to industrial treatments. Each treatment was conducted once, and a large batch of processed milk was obtained. The processed milk samples were taken for analysis directly after each treatment. All the analyses were conducted in triplicate, and the results were expressed as mean values \pm standard deviation. 


\subsection{High-temperature, short-time pasteurisation}

Both camel and bovine milk were pasteurised using an APV HXP pasteuriser (APV UK Limited, Crawley, West Sussex, UK). The holding section of the pasteuriser consisted of a plate-and-frame heat exchanger system. The pasteuriser unit was sterilised by circulating water at $85^{\circ} \mathrm{C}$ through the entire system prior to the treatment. The milk was then pasteurised at $72.5{ }^{\circ} \mathrm{C}$ and held for $15 \mathrm{~s}$ in a holding section. The pasteurised milk was cooled to $4{ }^{\circ} \mathrm{C}$ and collected in $500 \mathrm{~mL}$ sterile bottles (Ascott Ltd. Newton Abbot, UK).

\subsection{Ultra-high-temperature processing}

A tubular UHT plant (UHTAC, Fareins, France) was used for the indirect UHT treatment of camel and bovine milk. Heating was obtained in two stages using two hot oil baths. The unit was sterilised by circulating pressurised hot water prior to the treatment. The temperature of the milk samples was raised from 4 to $90{ }^{\circ} \mathrm{C}$ in a preheating unit (oil bath 1 ). The temperature was raised from 90 to $144{ }^{\circ} \mathrm{C}$ (oil bath 2), and the milk was held for $5 \mathrm{~s}$ at this temperature. The processed milk was cooled to $4{ }^{\circ} \mathrm{C}$ and collected in $500 \mathrm{~mL}$ sterile bottles.

\subsection{High-pressure treatment}

High-pressure treatment of camel and bovine milk was performed as described by Huppertz, Fox, and Kelly (2004a) Camel and bovine milk samples (50 mL) were vacuumpacked in polyethylene bags and HP-treated using a Stansted Iso-Lab 900 High Pressure Food Processor (Stansted Fluid Power, Stansted, Essex, UK), at pressures of 200, 400, 600, 
and $800 \mathrm{MPa}$ for $30 \mathrm{~min}$. The temperature of the HP unit vessel was maintained at $20{ }^{\circ} \mathrm{C}$. A mixture of water and 1,2-propanediol oil (70:30) was used as the pressurising fluid.

\subsection{Proximate composition analysis}

The chemical composition of raw skimmed and processed skimmed camel and bovine milk including the percentage of fat, total protein and lactose was determined using a LactoScope Filter Auto (QuadraChem Laboratories Ltd, Forest Row, UK). The machine was calibrated for skimmed milk analysis, and the samples $(100 \mathrm{~mL})$ were homogenised prior to analysis. The analyses were conducted in triplicate and the results were expressed as $\mathrm{g} 100$ $\mathrm{mL}^{-1}$.

\subsection{Determination of whey proteins denaturation}

Denaturation of whey proteins in camel and bovine milk samples was estimated by determining the level of residual native whey protein fractions: SA, $\alpha-1 \mathrm{a}, \beta-\lg$, and LF in milk by capillary electrophoresis (CE) (Agilent, Palo Alto, CA, United States) following the

method described by Omar, Harbourne and Oruna-Concha (2016). Briefly, the pH of the milk samples was adjusted to $\mathrm{pH} 4.3$ by adding $1 \mathrm{M} \mathrm{HCl}$. Then the samples were centrifuged at $4000 \times g$ at $4{ }^{\circ} \mathrm{C}$ for $15 \mathrm{~min}$ to separate the whey proteins from the precipitated casein. The supernatant, containing whey proteins was dialysed (dialysis sacks average flat width of 25 $\mathrm{mm}$, cut off 12,000 Da; Sigma-Aldrich) against distilled water and kept at $-18^{\circ} \mathrm{C}$ until analysis. Purified bovine milk proteins (BSA, $\beta-\lg , \alpha-\mathrm{la}, \mathrm{LF}$ ) at concentrations between 0.01 and $2.5 \mathrm{mg} \mathrm{mL}^{-1}$ were used to identify and quantify the proteins present in the milk samples. The degree of protein denaturation was expressed as the percentage of protein not detected 
compared with the untreated milk sample, which is stated to have a native protein percentage of $100 \%$ and thereby no denaturation.

\subsection{Determination of average casein micelle Size}

The casein micelle sizes in milk were determined using a Malvern Zetasizer Nano ZS (Malvern instruments Ltd., Malvern, Worcestershire, UK), as described by Chen, Grandison, and Lewis (2011).

\subsection{Determination of colour parameters}

Colour attributes were measured using the Hunter Lab Colour Quest (Hunter Associates Laboratory, Inc. Reston, VA, United States) according to Chugh et al. (2014). The colour values were expressed as $L^{*}$ (lightness), $a^{*}$ (redness to greenness), and $b^{*}$ (yellowness to blueness). To compare the total colour difference $(\Delta E)$ between the colour properties of untreated milk samples and those obtained after subjecting raw skimmed milk to different treatments (HTST, UHT, and HPP), the following equation was used:

$$
\Delta E=\sqrt{ } \Delta L^{*^{2}}+\Delta a^{*^{2}}+\Delta b^{*^{2}}
$$

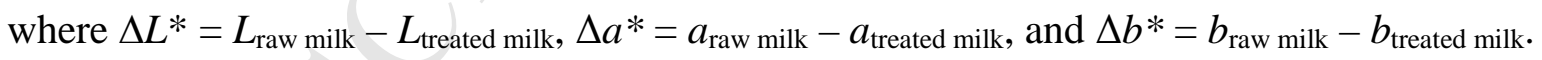

The whiteness (WI) of the milk samples was determined by converting Hunter Lab to CIE 1931 XYZ colour space values:

$$
\begin{aligned}
& \mathrm{Y}=\left(L^{*} / 10\right)^{2} \\
& \mathrm{X}=\left[\mathrm{Y}+\left(L^{*} / 10_{\mathrm{X}} a^{* / 17.5)}\right] / 1.02\right. \\
& \mathrm{Z}=\left[\mathrm{Y}-\left(b^{*} / 7\right)_{\mathrm{X}}\left(L^{*} / 10\right)\right] / 0.847 \\
& \mathrm{WI}=\left(3.388_{\mathrm{X}} \mathrm{Z}\right)-\left(3_{\mathrm{X}} \mathrm{Y}\right)
\end{aligned}
$$


Colour measurements were conducted in triplicate for each milk sample.

\subsection{Determination of rennet coagulation time and rheological properties of milk}

The rheological assessment of the rennet-induced coagulation of milk was performed with a Bohlin Gemini HRnano rheometer (Malvern Instruments Ltd) using a cylinder cup (27 $\mathrm{mm}$ inner diameter) and bob (25 mm outer diameter) system (Bohlin C-25; Malvern Instruments Ltd). The milk sample $(13 \mathrm{~mL})$ was pre-warmed in a water bath at $30{ }^{\circ} \mathrm{C}$ for 20 min, then $0.013 \mathrm{~mL}$ of a $0.4 \%(\mathrm{v} / \mathrm{v})$ liquid solution of rennet enzyme (Chr. Hansen) was added and the mixture was stirred for $1 \mathrm{~min}$ before being poured into the cup. The storage modulus, $G^{\prime}$, was measured at constant temperature of $30^{\circ} \mathrm{C}$ for $60 \mathrm{~min}$ at an applied strain of $1 \%$ and a frequency of $0.1 \mathrm{~Hz}$. The time point at which the storage modulus $G^{\prime}$ was $\geq 1 \mathrm{~Pa}$ was defined as the gelation time as described by Moynihan et al. (2014).

\subsection{Statistical analysis}

Analyses were performed in triplicate and results were presented as the mean \pm standard deviation. The analysis of variance (ANOVA) was used to compare the effects of the different treatments and the Tukey test was used to determine the differences between them at a 95\% confidence level (XL Stat Version 2015.6.01.24797, Kovach Computing Services, Wales, UK). Principal component analysis (PCA, Pearson n-1; XL Stat) was performed to differentiate between milk samples subjected to different processing methods.

\section{Results and discussion}




\subsection{Composition of thermally and high-pressure treated camel and bovine milk}

The mean values of protein, lactose, and total solids in the raw skimmed bovine milk

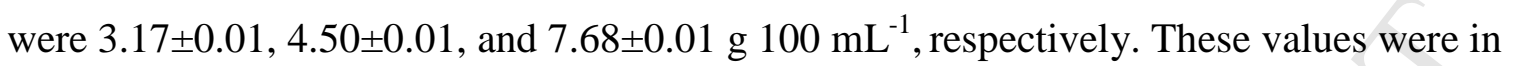
agreement with those in the literature (McSweeney \& Fox, 2013). In CM, the protein, lactose, and total solids were lower $\left(2.10 \pm 0.01,3.59 \pm 0.01\right.$, and $5.86 \pm 0.03 \mathrm{~g} 100 \mathrm{~mL}^{-1}$, respectively) than in bovine milk. These compositional variations were consistent with previously reported interspecies differences between camels' milk and cows' milk (Alhaj \& AlKanhal, 2010).

The compositional analysis of the processed CM revealed that the protein, lactose, and solids content after HTST treatment were similar to those of raw milk $(2.09 \pm 0.01$, $3.57 \pm 0.01$ and $5.86 \pm 0.01 \mathrm{~g} 100 \mathrm{~mL}^{-1}$, respectively). However, a slight variation in the protein content $\left(1.90 \pm 0.12 \mathrm{~g} 100 \mathrm{~mL}^{-1}\right)$ of CM was observed after UHT treatment, which might be due a decrease in soluble proteins. Whereas the lactose and total solids were not affected $\left(3.56 \pm 0.01,5.67 \pm 0.04 \mathrm{~g} 100 \mathrm{~mL}^{-1}\right.$, respectively). High-pressure treatments at 200-800 MPa did not alter the composition of CM.

3.2. Whey proteins denaturation of thermally and high-pressure treated camel and bovine milk

The levels of individual whey proteins in processed camel and bovine milk are presented in Table 1. The major identified whey protein in CM was $\alpha$-la, followed by LF and SA. The highest level of denaturation in camel whey proteins occurred in the UHT-treated CM sample, which was consistent with the results of its compositional analysis. Among the camel whey proteins, $\alpha$-la underwent the highest level of denaturation $(65.55 \pm 0.29 \%)$, 
followed by SA $(12.58 \pm 0.88 \%)$ and LF $(3.65 \pm 0.54 \%)$. In pasteurised CM, the amount of denatured $\alpha$-la was $27.13 \pm 3.23 \%$, considerably lower than that of UHT-treated CM, and only small denaturation in SA and LF was observed (2.97 \pm 0.65 and $1.13 \pm 0.51 \%$, respectively).

The results showed that $\alpha$-la was the most sensitive whey protein to HTST pasteurisation and UHT treatments. Similar findings were reported by Felfoul et al. (2017) who found that $\alpha$-la was the most heat-sensitive whey protein in $\mathrm{CM}$ heated at $80{ }^{\circ} \mathrm{C}$ for 60 min. High-pressure treatment of CM at $200 \mathrm{MPa}$ caused a lower level of denaturation of camel whey proteins compared with UHT treatment. However, increasing the pressure from 400 to $800 \mathrm{MPa}$ resulted in a significant increase in denatured $\alpha$-la up to $32.50 \pm 2.05 \%$, but this was still significantly lower than in the UHT treated samples. SA and LF were more resistant to pressure with lower denaturation levels of $3.94 \pm 0.07 \%$ and $2.93 \pm 0.38 \%$, respectively.

In contrast, $\beta$-lg was the primary whey protein in bovine milk, followed by $\alpha$-la and BSA. The levels of heat-induced denaturation of $\alpha$-la and BSA in bovine milk after HTST (4.23 \pm 1.37 , and $2.70 \pm 0.31 \%$, respectively) and UHT (51.06 \pm 2.11 and $5.37 \pm 1.46 \%$ respectively) treatments were considerably lower than those of their counterparts in heattreated CM. This finding is consistent with that observed by Felfoul et al. (2015a) and Sagar et al. (2016) who reported that camel $\alpha$-la and SA were less heat stable and their temperatures of denaturation were lower than their bovine counterparts.

Some studies have attributed the high heat sensitivity of camel whey proteins to the absence or deficiency of $\beta-\lg$ and $\kappa-\mathrm{CN}$ proteins in CM (Alhaj et al., 2011; Farah \& Atkins, 1992; Sagar et al., 2016). However, the variation in the thermal stability between the major whey protein in $\mathrm{CM} \alpha$-la and its bovine milk counterpart could be also due to differences in their conformational stabilities and structural features. The primary structure of the intact 
camel $\alpha$-la, as bovine $\alpha$-la, consists of 123 amino acids, but with 39 positional differences compared with bovine $\alpha$-la (Beg, Bahr-Lindström, Zaidi, \& Jörnvall, 1985).

Camel $\alpha$-la contains, 8 cysteine, 5 tryptophan, 4 phenylalanine, 3 methionine and 3 tyrosine residues, while its bovine counterpart contains 8 cysteine, 4 tryptophan, 4 phenylalanine, 1 methionine, and 4 tyrosine residues (Atri et al., 2010; Felfoul, Lopez, Gaucheron, Attia, \& Ayadi, 2015b). Atri et al., (2010) found that the conformation of both camel and bovine $\alpha$-la was sensitive to calcium removal. However, camel $\alpha$-la showed greater change in exposure of buried hydrophobic areas upon calcium depletion than its bovine equivalent. Redington, Breydo, Almehdar, Redwan, and Uversky (2016) reported that purified camel $\alpha$-la was more stable towards thermal denaturation than its bovine counterpart. However, it was less conformationally stable, aggregated faster and was more disordered than bovine $\alpha$-la.

Other factors such as $\mathrm{pH}$ and calcium concentration could also influence the stability of CM proteins (Levieux et al., 2006). Alhaj et al., (2011) reported that heat treatment of CM at high temperature $\left(121^{\circ} \mathrm{C}\right)$ induced precipitation of calcium phosphate, which led to casein micelle dissociation, and increased the calcium ion content with a decrease of milk $\mathrm{pH}$, which lowered the stability of milk proteins. Increasing level of soluble $\mathrm{Ca}^{2+}$ may neutralise the net negative charge on unfolded whey proteins which increases their thermal denaturation (Huppertz, Fox, \& Kelly, 2004b). Therefore, the higher level of thermal denaturation of whey proteins in $\mathrm{CM}$, compared with bovine milk, might be also due to an increase $\mathrm{Ca}^{2+}$ level as result of heat-induced disintegration of camel casein micelles (Table 2).

Unlike heat treatments, the stability of camel whey proteins was higher than that of their counterparts in bovine milk during HP processing. The level of denatured $\alpha-1 \mathrm{a}$ $(32.50 \pm 2.05 \%)$ after treatment at $800 \mathrm{MPa}$, was considerably lower than that of bovine milk $(55.23 \pm 1.66 \%)$, buffalo milk (91.8 $\pm 2.2 \%)$ (Huppertz et al., 2005) and ovine milk 
$(79.3 \pm 3.1 \%$ ) (Moatsou et al., 2008b). HP treatments induced the disintegration of casein micelle in bovine milk through disruption of hydrophobic, electrostatic interactions and solubilisation of colloidal calcium phosphate, resulting in an increased level of soluble calcium which may enhances denaturation of whey proteins (Huppertz et al., 2004b). Therefore, the lower extent of HP-induced denaturation of $\alpha$-la in CM compared with bovine milk might be explained by limited effect of HP treatments on casein micelle of CM (section 3.3). Furthermore, camel SA was more stable (3.94 $\pm 0.07 \%)$ at $800 \mathrm{MPa}$ than BSA $(16.17 \pm 1.85 \%)$, and LF was the most stable amongst camel whey proteins over both thermal and pressure treatments with only a small reduction in its concentration.

\subsection{Casein micelle size distribution in thermally and high-pressure treated camel and} bovine milk

The size distribution of casein micelles in raw skimmed camel and bovine milk was measured and the results indicated that the distribution of casein micelles in raw CM was broader and contained a higher proportion of large particles than in bovine milk. The average diameter of casein micelles in CM was $171.23 \pm 4.18 \mathrm{~nm}$; the corresponding value in bovine milk was $143.45 \pm 2.96 \mathrm{~nm}$. These results are consistent with data reported by Farah and Rüegg (1989). The effects of thermal and pressure treatments on casein micelle size in processed camel and bovine milk are listed in Table 2. The results revealed that HTST and UHT treatments caused a significant decrease in casein micelles size in CM by 16.4 and $19.5 \%$, respectively, compared with untreated milk. Micelle size in bovine milk was not significantly affected after HTST, and it increased by $14 \%$ after UHT treatment. Similar observations with bovine casein micelles have been reported by Freeman and Mangino (1981). Heat treatment of bovine milk at temperature above $80^{\circ} \mathrm{C}$ induces formation of $\beta$ - 
lg/ $\alpha$-la complexes through sulphydryl-disulphide interchange reactions, which then associate with the micelles and lead to an increase in their size (Oldfield, Singh, Taylor, \& Pearce, 2000). However, structural differences and variation in proportions of individual caseins between bovine and dromedary milk have been reported (Kappeler, Farah, \& Puhan, 1998). It has been established that a high content of $\beta-\mathrm{CN}$ and a low content of $\kappa-\mathrm{CN}$ adversely affect some of the processing characteristics of casein micelles such as stability towards ethanol and heat (Schmidt, 2009). In CM, $\beta-\mathrm{CN}$ is predominant while $\kappa-\mathrm{CN}$ is present in very small amount compared with the levels in bovine milk (Omar et al., 2016). Therefore, the significant decrease in the micelle size of heat-treated CM could possibly be due to the dissociation of $\kappa-\mathrm{CN}$ from micelles or the result of precipitation of calcium phosphate out of the casein micelles, which caused them to decrease in size (Anema \& Li, 2003).

After HP treatment, casein micelles in CM behaved differently than casein micelles in bovine milk. Treatment of CM at $200 \mathrm{MPa}$ caused a significant $(p<0.05)$ decrease in the size of casein micelles by $21 \%$ compared with untreated milk. After increasing the pressure from 400 to $800 \mathrm{MPa}$, a decrease of $25 \%$ in the size of micelle in CM was observed. Treatment of bovine milk at $200 \mathrm{MPa}$ caused a small reduction $(p<0.05)$ in micelle size by $6 \%$ compared with untreated milk. However, casein micelles in bovine milk were more susceptible to disintegrate due to increasing pressure (400-800 MPa) during HP treatment than were casein micelles in CM. Treatment at pressure 400 to $800 \mathrm{MPa}$ considerably reduced micelle size in bovine milk by $50 \%$ compared with controls. Similar observations of bovine casein micelles were reported by Huppertz et al. (2004a) and Needs et al. (2000).

Studies on goat milk by Law et al. (1998) found that treatments at $200 \mathrm{MPa}$ and temperatures between 20 and $45^{\circ} \mathrm{C}$ had little effect on casein micelle size. Treatment at 300 MPa caused an increase in micelle size due to the formation of insoluble aggregates of denatured $\beta$-lg with $\kappa-\mathrm{CN}$. However, higher pressures $(>350 \mathrm{MPa})$ at $45{ }^{\circ} \mathrm{C}$ caused a 
reduction in the size of casein micelles in goat milk. Different observations of buffalo milk have been reported by Huppertz et al. (2005) who found that treatment of buffalo milk at 250 $\mathrm{MPa}$ for $30 \mathrm{~min}$ at $20^{\circ} \mathrm{C}$ reduced micelle size slightly and that treatment at $\geq 400$ up to 800 MPa increased it by $35 \%$. The reduction in casein micelle size in bovine milk is likely to be due to the HP-induced disintegration of casein micelles into smaller particles via the disruption of the intra-micellar van der Waals, hydrophobic and electrostatic interactions and changes in the solubilisation of micellar calcium phosphate (Huppertz et al., 2006; Needs et al., 2000).

In contrast, the decrease in the size of casein micelles in CM was considerably smaller than that in bovine milk after HP treatments, which might be due to the differences in the primary structure of micelles between the two kinds of milk. The CM micelles have spherical shape, as do bovine milk micelles, but with relatively larger diameters and higher mineral content compared with bovine milk micelles (Hailu et al., 2016). Moreover, minerals such as magnesium, inorganic phosphorus and citrate are involved to a more important extent in the formation of the CM micelles, about 2/3, 2/3 and 1/3 respectively, than in bovine milk micelles (2/5, 3/5 and 1/10 respectively; Attia, Kherouatou, Nasri, \& Khorchani, 2000). Thus, they are more mineralised and contain more saline bridges binding submicelles than bovine milk (Kherouatou, Nasri, \& Attia, 2003). Nevertheless, further investigation is necessary to explain the reasons behind this phenomenon.

\subsection{Changes in the colour values of thermally and high-pressure treated camel and} bovine milk

The values of the Hunter colour attributes $L^{*}, a^{*}, b^{*}$, total colour difference $\Delta E$, and WI of processed camel and bovine milk samples compared with untreated skimmed milk are 
listed in Table 3. The HTST process caused a decrease in $L^{*}(p<0.05)$ and an increase in $a^{*}$ (greenness) and $b^{*}$ (yellowness) $(p<0.05)$ in both camel and bovine milk. The lowest $L^{*}$ value $(p<0.05)$ was observed in UHT-treated CM, which indicates increased darkness for the highest positive yellowness value $\left(b^{*}\right)$. This reduction in the lightness of CM during the UHT treatment may be the result of disintegration of casein micelles into smaller particles (Table 2). On the other hand, $L^{*}$ and $b^{*}$ were the highest $(p<0.05)$ in UHT-treated bovine milk, which indicates an increase in the lightness and yellowness of the milk. Similar results for bovine milk have been reported by Rufian-Henares, Guerra-Hernandez, and GarciaVillanova (2006). These authors found that after UHT treatment bovine milk had higher $a^{*}$ and $b^{*}$ values and that there was an increase in the lightness of milk by 11 units compared with the untreated samples. This increase in the lightness of UHT-treated bovine milk may be due to denaturation and association of whey proteins with casein micelles, in particular $\beta-\lg$ (Burton \& Rowland, 1955). The values of $\mathrm{WI}$ and $\Delta E$ in CM were markedly higher than those in bovine milk after UHT treatment.

High-pressure treatment of bovine milk at $200 \mathrm{MPa}$ caused a significant $(p<0.05)$ decrease in $L^{*}$ with an accompanying increase in $\Delta E$ and WI. Increasing the pressure up to $800 \mathrm{MPa}$ resulted in a further decrease in $L^{*}$ and an increase in $\Delta E$ and WI. Devi, Buckow, Singh, Hemar, and Kasapis (2015) reported similar findings on the behaviour of bovine milk colour under HP treatments. This significant reduction in $L^{*}$ of bovine milk is mainly attributed to the destruction of casein micelles by pressure into smaller particles, which increases the translucence of the milk. In contrast, a small reduction in $L^{*}$ in HP-treated CM by up to 1.88 units was observed after treatment at $200 \mathrm{MPa}$. Treatment at higher pressures $(\geq 400$ up to $800 \mathrm{MPa})$ resulted in a further decrease $(p<0.05)$ in $L^{*}$ in CM by up to 3.35 units. This slight reduction in $L^{*}$ in CM compared with bovine milk during HP treatments is possibly the result of the limited HP-induced disruption of its casein micelles (Table 2). 
Similar observations in buffalo milk have been reported by Huppertz et al. (2005) who found that treatments at 250 or $400 \mathrm{MPa}$ reduced $L^{*}$ of buffalo milk slightly and that treatment at 600 or $800 \mathrm{MPa}$ reduced $L^{*}$ significantly, by up to 17 units after treatment at 800 MPa. The results revealed that $\Delta E$ and WI of CM significantly increased $(p<0.05)$ with increasing pressure $(200,400,600$, and $800 \mathrm{MPa})$. These parameters attained maximum values of 3.57 and 16.83 , respectively, after treatment at $800 \mathrm{MPa}$. The degree of change of these values in CM was considerably less than that of bovine milk. Furthermore, the HPtreated bovine milk had more yellow and green characteristics than CM after treatments at 400, 600, and $800 \mathrm{MPa}$. Gervilla et al. (2001) reported a decrease in $L^{*}$ and an increase in greenness and yellowness in ewes' milk when the pressure was incrementally increased to 200, 300, 400, and $500 \mathrm{MPa}$ during HP treatment. These changes were due to HP-induced disruption of casein micelles in ewes' milk.

\subsection{Rennet coagulation properties of thermally and high-pressure treated camel and} bovine milk

The development of rennet-induced coagulum in camel and bovine milk was monitored using dynamic oscillatory rheology. The effect of thermal and HP treatments on the storage modulus $G^{\prime}$ of camel and bovine milk after renneting for $60 \mathrm{~min}$ at $30{ }^{\circ} \mathrm{C}$ is shown in Fig. 1. The initial $\mathrm{pH}$ of the $\mathrm{CM}$ samples prior to the addition of rennet (Table 4) varied between 6.71 and 6.51, consistent with the reported $\mathrm{pH}$ values of $\mathrm{CM}$ in the literature (Farah, 1993). The final $\mathrm{pH}$ values of the gel formed after 60 min incubation were ranged from 6.326.64, which was lower than those measured for the curd formed by the bovine milk.

The RCT of the raw CM was much shorter than that of bovine milk. Camel chymosin initiates coagulation of milk by hydrolysing bovine $\kappa-\mathrm{CN}$ at the $\mathrm{Phe}^{105}-\mathrm{Met}^{106}$ scissile bond 
and disconnecting the C-terminal part of 106-169 amino acids (Langholm Jensen et al., 2013). Whereas, the chymosin cleavage site of camel $\kappa-\mathrm{CN}$ is at the $\mathrm{Phe}^{97}-\mathrm{Ile}^{98}$ bond and the enzyme cuts off a C-terminal glycomacropeptide of 65 amino acids residues (Hailu et al., 2016). The coagulation of CM occurs only after hydrolysis of $95 \%$ of camel $\kappa-\mathrm{CN}$ by camel chymosin, while, the gelation of bovine milk starts at level of $60-70 \%$ of bovine $\mathrm{k}-\mathrm{CN}$ hydrolysis (Hailu et al., 2016). The HTST treatment of CM at $72.5^{\circ} \mathrm{C}$ for 15 s significantly $(p$ $<0.05$ ) delayed the RCT of the milk by $70.99 \%$ compared with untreated milk (Table 4 ) and the final $G^{\prime}$ value was considerably lower than that of the control (Fig. 1A). The RCT of bovine milk was also significantly delayed after HTST by $14.36 \%$ and the $G^{\prime}$ value was decreased, but not statistically significant, compared with untreated milk. Similar results about the effects of heat treatment on the RCT of bovine (Singh \& Waungana, 2001), ewe, and goat milk (Calvo \& Balcones, 1998) clotted using bovine chymosin have been reported. Kethireddipalli and Hill (2015) noted that heat treatment at temperatures above $75^{\circ} \mathrm{C}$ led to an increase in the RCT of milk and the formation of weak curds. Vasbinder, Rollema, and Kruif (2003) and Blecker, Habib-Jiwan, and Karoui (2012) reported that the decrease in the rate of gel development and final $G^{\prime}$ value in pasteurised milk could be the result of the association of denatured whey protein aggregates with casein micelle surfaces. The formation of whey protein- $\kappa$-casein complex affects the reactive sites on the micelles that are formed by the action of rennet, which leads to fewer and weaker bonds and therefore a weaker coagulum (Singh \& Waungana, 2001).

As expected, UHT-treated camel and bovine milk failed to coagulate. Similar observations have been found using bovine chymosin in bovine milk by Ham et al. (2013). These authors found that UHT treatment hindered the coagulation of milk compared with HTST treatment. This heat-induced inhibition of rennet coagulation is mainly attributed to effects arising during the secondary stage of rennet coagulation or micelle aggregation, the 
decreased concentration of ionic calcium, and the association of denatured whey proteins with the casein micelles in heat-treated milk (Vasbinder et al., 2003).

In HP treatment, the RCT of bovine milk treated at $200 \mathrm{MPa}$ was shortened significantly $(p<0.05)$ by $26.91 \%$ (Table 3 ) and the $G^{\prime}$ value was the highest (Fig. 1B) compared with the control milk. However, HP treatments at higher pressures $(400,600$, and $800 \mathrm{MPa}$ ) resulted in an increase of the RCT and the final $G^{\prime}$ value was similar to untreated milk. These results are consistent with previously reported observations for bovine milk coagulated with recombinant bovine chymosin by Needs et al. (2000) and Zobrist, Huppertz, Uniacke, Fox, and Kelly (2005). The reduction in the RCT of bovine milk after HP treatment at $200 \mathrm{MPa}$ is believed to be the result of the dissociation of micellar $\kappa$-casein and the disruption of casein micelles, which led to an increase in the surface area for intermicellar interactions with less $\kappa$-casein available to provide steric stabilisation (Huppertz et al., 2006; Needs et al., 2000).

In contrast, the rheological properties of CM differed from that of bovine milk for HP treatments. The HP treatment at 200 and $400 \mathrm{MPa}$ significantly $(p<0.05)$ delayed the RCT of CM by 55.90 and $109.39 \%$, respectively, compared with untreated milk. The rate of gel formation in HP-treated CM at $200 \mathrm{MPa}$ (Fig. 1A) was lower than that of untreated milk during the first $30 \mathrm{~min}$, following the addition of rennet enzymes. However, after $40 \mathrm{~min}$ the rate of increase of $G^{\prime}$ was higher than that of control milk and the final value of $G^{\prime}$ after 60 min of incubation was the highest. This increase in the RCT and strength of the rennetinduced coagulum from CM treated at $200 \mathrm{MPa}$ might be due to restricted effect of $\mathrm{HP}$ on disruption of casein micelles and whey protein denaturation in CM. In HP-treated CM at 400 $\mathrm{MPa}$, the rate of coagulum formation was considerably slower with a significantly lower final $G^{\prime}$ value than that of untreated milk. Meanwhile, no progress in the rennet-induced coagulum was observed in CM treated at 600 and $800 \mathrm{MPa}$. Similar observations regarding effect of HP 
treatments on the RCT of buffalo milk coagulated with bovine chymosin (Maxiren 180) have been reported by Huppertz et al. (2005). These authors found that HP treatment at $100 \mathrm{MPa}$ had no effect on the RCT of buffalo milk. On the other hand, the RCT of buffalo milk increased significantly by $50 \%$ after treatment at $200 \mathrm{MPa}$ and continued to increase with pressure to a maximum of $100 \%$ after treatment at $800 \mathrm{MPa}$. In another study by LópezFandiño and Olano (1998), the RCT of ovine milk, clotted using standard bovine chymosin, increased significantly after treatment at 200 and $300 \mathrm{MPa}$, but treatment at $400 \mathrm{MPa}$ decreased the RCT. These authors also found that HP treatment of caprine milk at $200 \mathrm{MPa}$ did not affect the RCT, and treatment at 300 and $400 \mathrm{MPa}$ increased the RCT.

To visualise the effects of the different treatments on CM properties, principal component analysis (PCA) was used (Fig. 2). The two principal components accounted for $82 \%$ of the variation in the data. Processed CM samples were separated according to intensity of heat and high-pressure along PC1, which explains $62.20 \%$ of the total variance in the data. UHT CM was clearly separated from the raw and the pasteurised milk, while HP-treated CM samples at 600 and $800 \mathrm{MPa}$ were clustered in the upper right tope of the PCA. These CM samples were correlated with the highest levels of denaturation of whey proteins and maximum colour difference $(\Delta E)$. On the other hand, the PCA revealed a distinct separation between HP-treated CM samples and HTST and UHT milk samples along the second PC, which explains $20.11 \%$ of the variability. CM samples treated at 200 and $400 \mathrm{MPa}$ were associated with the RCT, $G^{\prime}$ and WI. While, raw and pasteurised CM were correlated with the size of casein micelle.

\section{Conclusions}


Heat and pressure treatments considerably affected many constituents and properties of CM. In UHT CM the colour change, and level of whey proteins denaturation were markedly greater than those observed in pasteurised and HP-treated CM. While, casein micelles size was significantly decreased in both heated and HP-treated CM. The RCT of CM was significantly delayed and coagulum strength $\left(G^{\prime}\right)$ decreased after HTST pasteurisation. $\mathrm{HP}$ treatment at $200 \mathrm{MPa}$ increased the RCT and enhanced the $G^{\prime}$ value of CM. However, treatment at pressures higher than $400 \mathrm{MPa}$ impaired the rennet coagulation properties of $\mathrm{CM}$. These findings will be beneficial to the dairy processors in terms of design, evaluation and optimisation conditions of industrial operations such as pasteurisation and UHT for camel milk processing. They also can be helpful for evaluating the potential commercial use of HP treatment for CM preservation as an alternative to thermal methods, and in developing and manufacturing of various dairy products from CM.

\section{Acknowledgement}

This research did not receive any specific grant from funding agencies in the public, commercial, or not-for-profit sectors.

\section{References}

Alhaj, O. A., \& AlKanhal, H. A. (2010). Compositional, technological and nutritional aspects of dromedary camel milk. International Dairy Journal, 20, 811-821.

Alhaj, O. A., Metwalli, A. A. M., \& Ismail, 1. A. (2011). Heat stability of camel milk proteins after sterilisation process. Journal of Camel Practice and Research, 18, 277-282. 
Anema, S. G., \& Li, Y. ( 2003). Association of denatured whey proteins with casein micelles in heated reconstituted skim milk and its effect on casein micelle size. Journal of Dairy Research, 70, 73-83.

Atri, M. S., Saboury, A. A., Yousefi, R., Dalgalarrondo, M., Chobert, J. M., Haertlé, T., et al. (2010). Comparative study on heat stability of camel and bovine apo and hollo $\alpha$ lactalbumin. Journal of Dairy Research, 77, 43-49.

Attia, H., Kherouatou, N., Nasri, M., \& Khorchani, T. (2000). Characterization of the dromedary milk casein micelle and study of its changes during acidification. Lait, 80, $503-515$.

Beg, O. U., Bahr-Lindström, H. von, Zaidi, Z. H., \& Jörnvall, H. (1985). The primary structure of $\alpha$-lactalbumin from camel milk. FEBS Journal, 147, 233-239.

Benabdelkamel, H., Masood, A., Alanazi, I. O., Alzahrani, D. A., Alrabiah, D. K., AlYahya, S. A., et al. (2017). Proteomic profiling comparing the effects of different heat treatments on camel (Camelus dromedarius) milk whey proteins. International Journal of Molecular Sciences, 18, 2-15.

Blecker, C., Habib-Jiwan, J. M., \& Karoui, R. (2012). Effect of heat treatment of rennet skim milk induced coagulation on the rheological properties and molecular structure determined by synchronous fluorescence spectroscopy and turbiscan. Food Chemistry, 135, 1809-1817.

Burton, H., \& Rowland, S. J. (1955). Colour changes in heated and unheated milk. III The effect of variation in milk composition on the whitening and browning of separated milk heating. Journal of Dairy Research, 22, 82-90.

Calvo, M. M., \& Balcones, E. (1998). Influence of heat treatment on rennet clotting properties of mixtures of cows', ewes', and goats' milk and on cheese yield. Journal of Agricultural and Food Chemistry, 46, 2957-2962. 
Chen, B. Y., Grandison, A. S., \& Lewis, M. J. (2011). Comparison of heat stability of goat milk subjected to ultra-high temperature and in-container sterilization. Journal of Dairy Science, 95, 1057-1063.

Chugh, A., Khanal, D., Walkling-Ribeiro, M., Corredig, M., Duizer, L., \& Griffiths, M. W. (2014). Change in colour and volatile composition of skim milk processed with pulsed electric field and microfiltration treatments or heat pasteurization. Foods, 3 , $250-268$.

Devi, A. F., Buckow, R., Singh, T., Hemar, Y., \& Kasapis, S. (2015). Colour change and proteolysis of skim milk during high pressure thermal-processing. Journal of Food Engineering, 147, 102-110.

Elagamy, E. I. (2000). Effect of heat treatment on camel milk proteins with respect to antimicrobial factors: a comparison with cows' and buffalo milk proteins. Food Chemistry, 68, 227-232.

Farah, Z. (1993). Composition and characteristics of camel milk. Journal of Dairy Research, $60,603-626$.

Farah, Z. \& Atkins, D. (1992). Heat coagulation of camel milk. Journal of Dairy Research, $59,229-231$.

Farah, Z., Rüegg, M. W. (1989). The size distribution of casein micelles in camel milk. Food Microstructure, 8, 211-216.

Felfoul, I., Jardin, J., Gaucheron, F., Attia, H., \& Ayadi, M. A. (2017). Proteomic profiling of camel and cow milk proteins under heat treatment. Food Chemistry, 216,161-169.

Felfoul, I., Lopez, C., Gaucheron, F., Attia, H., \& Ayadi, M. A. (2015a). A laboratory investigation of cow and camel whey proteins deposition under different heat treatments. Food and Bioproducts Processing, 96, 256-263. 
Felfoul, I., Lopez, C., Gaucheron, F., Attia, H., \& Ayadi, M. A. (2015b). Fouling behavior of camel and cow milks under different heat treatments. Food and Bioprocess Technology, 8, 1771-1778.

Freeman, N.W., \& Mangino, M.E. (1981). Effects of ultra-high temperature processing on size and appearance of casein micelles in bovine milk. Journal of Dairy Science, 64, $1772-1780$.

Gervilla, R., Ferragut, V., \& Guamis, B. (2001). High hydrostatic pressure effects on colour and milk-fat globule of ewe's milk. Journal of Food Science, 66, 880-885.

Hailu, Y., Hansen, E. B., Seifu, E., Eshetu, M., Ipsen, R., \& Kappeler, S. (2016). Functional and technological properties of camel milk proteins: A review. Journal of Dairy Research, 83, 422-429.

Ham, J. S., Shin, J. H., Noh, Y. B., Jeong, S. G., Han, G. S., Chae, H. S., et al. (2013). Chemical and microbiological quality, capillary electrophoresis pattern, and rennet coagulation of UHT-treated and irradiated milk. Food Science and Biotechnology, 17, $58-65$.

Huppertz, T., Fox, P. F., \& Kelly, A. L. (2004a). High pressure treatment of bovine milk: effects on casein micelles and whey proteins. Journal of Dairy Research, 71, 97-106.

Huppertz, T., Fox, P. F., \& Kelly, A. L. (2004b). High pressure-induced denaturation of $\alpha-$ lactalbumin and $\beta$-lactoglobulin in bovine milk and whey: a possible mechanism. Journal of Dairy Research, 71, 489-495.

Huppertz, T., Smiddy, M. A., Upadhyay, V., \& Kelly, A. L. (2006). High-pressure-induced changes in bovine milk: A review. International Journal of Dairy Technology, 59, $58-66$. 
Huppertz, T., Zobrist, M. R., Uniacke, T., Upadhyat, V., Fox, P. F., \& Kelly, A. L. (2005). Effects of high pressure on some constituents and properties of buffalo milk. Journal of Dairy Research, 72, 226-233.

Jilo, K., \& Tegegne, D. (2016). Chemical composition and medicinal values of camel milk. International Journal of Research Studies in Biosciences, 4, 13-25.

Kappeler, S., Farah, Z., \& Puhan, Z. (1998). Sequence analysis of Camelus dromedarius milk caseins. Journal of Dairy Research, 65, 209-222.

Kaskous, S. (2016). Importance of camel milk for human health. Emirates Journal of Food and Agriculture, 28, 158-163.

Kethireddipalli, P., \& Hill, A. R. (2015). Rennet coagulation and cheesemaking properties of thermally processed milk: overview and recent developments. Journal of Agricultural and Food Chemistry, 63, 9389-9403.

Kherouatou, N., Nasri, M., \& Attia, H. (2003). A study of the dromedary milk casein micelle and its changes during acidification. Brazilian Journal of Food Technology, 6, 237244.

Laleye, L. C., Jobe, B., \& Wasesa, A. A. H. (2008). Comparative study on heat stability and functionality of camel and bovine milk whey proteins. Journal of Dairy Science, 91, $4527-4534$.

Langholm Jensen, J., Mølgaard, A., Navarro Poulsen, J. -C., Harboe, M. K., Simonsen, J. B., Lorentzen, A. M., et al. (2013). Camel and bovine chymosin: the relationship between their structures and cheese-making properties. Acta Crystallographica Section D: Biological Crystallography, 69, 901-913.

Law, A. J. R., Leaver, J., Felipe, X., Ferragut, V., Pla, R., \& Guamis, B. (1998). Comparison of the effects of high pressure and thermal treatments on the casein micelles in goats' milk. Journal of Agricultural and Food Chemistry, 46, 2523-2530. 
Levieux, D., Levieux, A., El-Hatmi, H., \& Rigaudie, J. -P. (2006). Immunochemical quantification of heat denaturation of camel (Camelus dromedarius) whey proteins. Journal of Dairy Research, 73, 1-9.

López-Fandiño, R. (2006). High pressure-induced changes in milk proteins and possible applications in dairy technology. International Dairy Journal, 16, 1119-1131.

López-Fandiño, R., \& Olano, A. (1998). Cheese-making properties of ovine and caprine milks submitted to high pressures. Lait, 78, 341-350.

McSweeney, P. L. H., \& Fox, P. F. (2013). Advanced dairy chemistry. Vol. 1A. Proteins: Basic aspects. (4th ed). New York, NY, USA: Springer.

Moatsou, G., Bakopanos, C., Katharios, D., Katsaros, G., Kandarakis, I., Taoukis, P., et al. (2008a). Effect of high-pressure treatment at various temperatures on indigenous proteolytic enzymes and whey protein denaturation in bovine milk. Journal of Dairy Research, 75, 262-269.

Moatsou, G., Katsaros, G., Bakopanos, C., Kandarakis, I., Taoukis, P., \& Politis, I. (2008b). Effect of high-pressure treatment at various temperatures on activity of indigenous proteolytic enzymes and denaturation of whey proteins in ovine milk. International Dairy Journal, 18, 1119-1125.

Moynihan, A. C., Govindasamy-Lucey, S., Jaeggi, J. J., Johnson, M. E., Lucey, J. A., \& McSweeney, P. L. H. (2014). Effect of camel chymosin on the texture, functionality, and sensory properties of low-moisture, part-skim Mozzarella cheese. Journal of Dairy Science, 97, 85-96.

Needs, E. C., Stenning, R. A., Gill, A., Ferragut, V., \& Rich, G. T. (2000). High-pressure treatment of milk: effects on casein micelle structure and on enzymic coagulation. Journal of Dairy Research, 67, 31-42. 
Oldfield, D. J., Singh, H., Taylor, M. W., \& Pearce, K. N. (2000). Heat-induced interactions of $\beta$-lactoglobulin and $\alpha$-lactalbumin with the casein micelle in $\mathrm{pH}$-adjusted skim milk. International Dairy Journal, 10, 509-518.

Omar, A., Harbourne, N., \& Oruna-Concha, M. J. (2016). Quantification of major camel milk proteins by capillary electrophoresis. International Dairy Journal, 58, 31-35.

Redington, J. M., Breydo, L., Almehdar, H. A., Redwan, E. M., \& Uversky, V. N. (2016). $\alpha-$ Lactalbumin: Of camels and cows. Protein and Peptide Letters, 23, 1072-1080.

Rufian-Henares, J. A., Guerra-Hernandez, E., \& Garcia-Villanova, B. (2006). Colour measurement as indicator for controlling the manufacture and storage of enteral formulas. Food Control, 17, 489-493.

Sagar, S. P., Mehta, B. M., Wadhwani, K. N., Darji, V. B., \& Aparnathi, K. D. (2016). Evaluation of camel milk for selected processing related parameters and comparisons with cow and buffalo milk. International Journal of Health, Animal Science and Food Safety, 3, 27-37.

Schmidt, D. G. (2009). Properties of artificial casein micelles. Journal of Dairy Research, 46, $351-355$.

Singh, H., \& Waungana, A. (2001). Influence of heat treatment of milk on cheesemaking properties. International Dairy Journal, 11, 543-551.

Trujillo, A. J., Capellas, M., Saldo, J., Gervilla, R., \& Guamis, B. (2002). Applications of high-hydrostatic pressure on milk and dairy products: a review. Innovative Food Science and Emerging Technologies, 3, 295-307.

Vasbinder, A. J., Rollema, H. S., \& Kruif, C. G. D. (2003). Impaired rennetability of heated milk; study of enzymatic hydrolysis and gelation kinetics. Journal of Dairy Science, $86,1548-1555$. 
Zobrist, M. R., Huppertz, T., Uniacke, T., Fox, P. F., \& Kelly, A. L. (2005). High-pressureinduced changes in the rennet coagulation properties of bovine milk. International Dairy Journal, 15, 655-662. 


\section{Figure legends}

2

3 Fig. 1. Influence of incubation time at $30^{\circ} \mathrm{C}$ following addition of rennet on the storage

4 modulus, $G^{\prime}$, of processed camel (A) and bovine (B) milk, raw skimmed untreated milk (O),

$5 \operatorname{HTST}\left(72{ }^{\circ} \mathrm{C}, 15 \mathrm{~s}\right)$ milk $(\diamond)$, UHT $\left(140{ }^{\circ} \mathrm{C}, 5 \mathrm{~s}\right)$ milk $(\boldsymbol{\Delta})$, high-pressure at $200(*), 400$

$6(\triangle), 600(\times), 800(\bigcirc) \mathrm{MPa}$ for $30 \mathrm{~min}$ at $20^{\circ} \mathrm{C}$. Values are means of data from experiments

7 on three individual milk samples.

8

9 Fig. 2. Principal component analysis of skimmed CM samples subjected to HTST $\left(72{ }^{\circ} \mathrm{C}, 15\right.$

$10 \mathrm{~s})$ and $\mathrm{UHT}\left(140{ }^{\circ} \mathrm{C}, 5 \mathrm{~s}\right)$ and high-pressure (HP) at $200,400,600,800 \mathrm{MPa}$ for $30 \mathrm{~min}$ at 20

$11{ }^{\circ} \mathrm{C}$, and variables: final storage modulus $\left(G^{\prime}\right)$, whiteness (WI), rennet coagulation time (RCT),

12 total colour difference $(\Delta E)$, and denaturation of whey protein $(\%)$ : serum albumin $(\mathrm{SA})$,

13 lactoferrin (LF), and $\alpha$-lactalbumin ( $\alpha$-la). 


\section{Table 1}

2 Major whey proteins $\beta$-lactoglobulin ( $\beta$-lg), $\alpha$-lactalbumin $(\alpha$-la), serum albumin (SA), and lactoferrin (LF) identified in raw and processed

3 skimmed camel and bovine milk. ${ }^{\mathrm{a}}$

\begin{tabular}{|c|c|c|c|c|c|c|c|c|}
\hline \multirow[t]{3}{*}{ Treatment } & \multicolumn{8}{|c|}{ Whey protein content $\left(\mathrm{mg} \mathrm{mL}^{-1}\right)$} \\
\hline & \multicolumn{2}{|l|}{$\beta-\lg$} & \multicolumn{2}{|l|}{$\alpha-1 a$} & \multicolumn{2}{|l|}{ SA } & \multicolumn{2}{|l|}{$\mathrm{LF}$} \\
\hline & Camel & Bovine & Camel & Bovine & Camel & Bovine & Camel & Bovine \\
\hline HTST & - & $4.18 \pm 0.16^{\mathrm{a}}$ & $1.43 \pm 0.12^{\mathrm{b}}$ & $1.04 \pm 0.01^{\mathrm{ab}}$ & $0.39 \pm 0.00^{\mathrm{b}}$ & $0.41 \pm 0.01^{\mathrm{ab}}$ & $1.72 \pm 0.00^{\mathrm{ab}}$ & - \\
\hline UHT & - & $0.80 \pm 0.01^{\mathrm{c}}$ & $0.68 \pm 0.03^{c}$ & $0.53 \pm 0.02^{\mathrm{d}}$ & $0.35 \pm 0.01^{\mathrm{c}}$ & $0.40 \pm 0.01^{\mathrm{b}}$ & $1.68 \pm 0.00^{\mathrm{d}}$ & - \\
\hline HP400 & - & $1.98 \pm 0.18^{\mathrm{bc}}$ & $1.39 \pm 0.04^{b}$ & $0.81 \pm 0.01^{\mathrm{c}}$ & $0.40 \pm 0.00^{\mathrm{ab}}$ & $0.37 \pm 0.00^{\mathrm{c}}$ & $1.69 \pm 0.01^{\mathrm{c}}$ & - \\
\hline HP600 & - & $1.14 \pm 0.06^{\mathrm{c}}$ & $1.35 \pm 0.03^{\mathrm{b}}$ & $0.53 \pm 0.01^{\mathrm{d}}$ & $0.39 \pm 0.00^{\mathrm{b}}$ & $0.36 \pm 0.00^{\mathrm{cd}}$ & $1.69 \pm 0.00^{c}$ & - \\
\hline HP800 & - & $1.05 \pm 0.07^{\mathrm{c}}$ & $1.32 \pm 0.01^{\mathrm{b}}$ & $0.48 \pm 0.01^{\mathrm{d}}$ & $0.39 \pm 0.00^{\mathrm{b}}$ & $0.35 \pm 0.01^{\mathrm{d}}$ & $1.69 \pm 0.00^{\mathrm{cd}}$ & - \\
\hline
\end{tabular}

4

${ }^{\text {a }}$ Processing parameters were: HTST $72{ }^{\circ} \mathrm{C}, 15 \mathrm{sec}$; UHT, $140{ }^{\circ} \mathrm{C}$, $5 \mathrm{sec}$; high-pressure (HP), 200, 400, 600, $800 \mathrm{MPa}$ for 30 min at $20{ }^{\circ} \mathrm{C}$. Values are means \pm standard deviation $(\mathrm{n}=3$; -, not detected); means within a column with different superscript letters are significantly different $(p<$ 0.05). 


\section{$9 \quad$ Table 2}

10 The average diameter of casein micelle size in raw and processed skimmed camel and bovine

11 milk. $^{\text {a }}$

\begin{tabular}{lllr}
\hline Treatment & \multicolumn{2}{l}{ Casein micelle size $(\mathrm{nm})$} & 12 \\
\cline { 2 - 4 } & Camel milk & Bovine milk & 13 \\
\hline Raw skimmed milk & $171.23 \pm 4.18^{\mathrm{a}}$ & $143.45 \pm 2.96^{\mathrm{b}}$ & 14 \\
HTST & $143.18 \pm 2.34^{\mathrm{b}}$ & $140.05 \pm 2.29^{\mathrm{b}}$ & 15 \\
UHT & $137.77 \pm 1.52^{\mathrm{c}}$ & $163.60 \pm 3.70^{\mathrm{a}}$ & 16 \\
HP200 & $135.22 \pm 2.68^{\mathrm{c}}$ & $134.90 \pm 1.52^{\mathrm{c}}$ & 16 \\
HP400 & $128.28 \pm 2.75^{\mathrm{d}}$ & $73.13 \pm 0.54^{\mathrm{d}}$ & 17 \\
HP600 & $127.57 \pm 1.76^{\mathrm{d}}$ & $70.96 \pm 0.59^{\mathrm{d}}$ & 18 \\
HP800 & $129.40 \pm 0.78^{\mathrm{d}}$ & $71.52 \pm 0.81^{\mathrm{d}}$ & \\
\hline
\end{tabular}

$19{ }^{\mathrm{a}}$ Processing parameters were: HTST $72{ }^{\circ} \mathrm{C}, 15 \mathrm{sec}$; UHT, $140{ }^{\circ} \mathrm{C}$, $5 \mathrm{sec}$; high-pressure (HP), $20200,400,600,800 \mathrm{MPa}$ for $30 \mathrm{~min}$ at $20^{\circ} \mathrm{C}$. Values are means \pm standard deviation $(\mathrm{n}=3)$; 21 means within a column with different superscript letters are significantly different $(p<0.05)$. 
23 Changes of colour parameters, $L^{*}$ (lightness), $a^{*}$ (redness to greenness), $b^{*}$ (yellowness to blueness), total colour difference ( $\Delta E$ ), and whiteness

24 (WI) measured in raw and processed skimmed camel and bovine. ${ }^{\mathrm{a}}$

\begin{tabular}{llllll}
\hline Treatment & $L^{*}$ & $a^{*}$ & $b^{*}$ & $\Delta E$ & WI \\
\hline Camel milk & & & & \\
Raw skim milk & $67.77 \pm 0.29^{\mathrm{a}}$ & $-1.99 \pm 0.37^{\mathrm{d}}$ & $-0.23 \pm 0.19^{\mathrm{b}}$ & $0 \pm 0.0^{\mathrm{e}}$ & $14.47 \pm 0.81^{\mathrm{b}}$ \\
HTST & $66.34 \pm 0.12^{\mathrm{b}}$ & $-1.97 \pm 0.11^{\mathrm{d}}$ & $-0.22 \pm 0.38^{\mathrm{b}}$ & $1.48 \pm 0.10^{\mathrm{d}}$ & $14.13 \pm 1.44^{\mathrm{b}}$ \\
UHT & $61.83 \pm 0.33^{\mathrm{d}}$ & $-1.19 \pm 0.12^{\mathrm{a}}$ & $0.45 \pm 0.43^{\mathrm{a}}$ & $6.05 \pm 0.34^{\mathrm{a}}$ & $10.78 \pm 1.57^{\mathrm{c}}$ \\
HP200 & $65.89 \pm 0.55^{\mathrm{b}}$ & $-2.46 \pm 0.16^{\mathrm{e}}$ & $-1.23 \pm 0.44^{\mathrm{c}}$ & $2.26 \pm 0.35^{\mathrm{c}}$ & $17.85 \pm 1.75^{\mathrm{a}}$ \\
HP400 & $64.01 \pm 0.32^{\mathrm{c}}$ & $-1.44 \pm 0.12^{\mathrm{ab}}$ & $-1.13 \pm 0.10^{\mathrm{c}}$ & $3.91 \pm 0.32^{\mathrm{b}}$ & $16.93 \pm 0.31^{\mathrm{a}}$ \\
HP600 & $64.43 \pm 0.46^{\mathrm{c}}$ & $-1.91 \pm 0.04^{\mathrm{cd}}$ & $-1.03 \pm 0.10^{\mathrm{c}}$ & $3.44 \pm 0.45^{\mathrm{b}}$ & $16.69 \pm 0.45^{\mathrm{a}}$ \\
HP800 & $64.42 \pm 0.14^{\mathrm{c}}$ & $-1.63 \pm 1.33^{\mathrm{bc}}$ & $-1.07 \pm 0.14^{\mathrm{c}}$ & $3.57 \pm 0.13^{\mathrm{b}}$ & $16.84 \pm 0.56^{\mathrm{a}}$ \\
& & & & \\
Bovine milk & & & & \\
Raw skim milk & $66.81 \pm 0.05^{\mathrm{b}}$ & $-3.53 \pm 0.1^{\mathrm{b}}$ & $-0.25 \pm 0.08^{\mathrm{b}}$ & $0 \pm 0.0^{\mathrm{e}}$ & $14.33 \pm 0.33^{\mathrm{c}}$ \\
HTST & $66.77 \pm 0.17^{\mathrm{b}}$ & $-3.11 \pm 0.17^{\mathrm{ab}}$ & $-0.21 \pm 0.31^{\mathrm{b}}$ & $0.61 \pm 0.15^{\mathrm{e}}$ & $14.15 \pm 1.30^{\mathrm{c}}$ \\
UHT & $68.94 \pm 0.22^{\mathrm{a}}$ & $-2.98 \pm 0.22^{\mathrm{ab}}$ & $1.51 \pm 0.79^{\mathrm{a}}$ & $2.93 \pm 0.14^{\mathrm{d}}$ & $7.83 \pm 3.16^{\mathrm{d}}$ \\
HP200 & $59.99 \pm 0.46^{\mathrm{c}}$ & $-2.53 \pm 0.13^{\mathrm{a}}$ & $-1.27 \pm 1.45^{\mathrm{b}}$ & $7.08 \pm 0.61^{\mathrm{c}}$ & $16.34 \pm 4.90^{\mathrm{c}}$ \\
HP400 & $49.51 \pm 0.42^{\mathrm{d}}$ & $-2.30 \pm 0.71^{\mathrm{a}}$ & $-9.61 \pm 0.46^{\mathrm{c}}$ & $19.72 \pm 0.43^{\mathrm{b}}$ & $37.11 \pm 1.39^{\mathrm{a}}$ \\
HP600 & $47.13 \pm 0.74^{\mathrm{e}}$ & $-3.01 \pm 0.95^{\mathrm{ab}}$ & $-9.85 \pm 0.29^{\mathrm{c}}$ & $21.92 \pm 0.70^{\mathrm{a}}$ & $35.97 \pm 0.96^{\mathrm{ab}}$ \\
HP800 & $45.78 \pm 0.87^{\mathrm{f}}$ & $-2.67 \pm 0.63^{\mathrm{ab}}$ & $-8.95 \pm 0.29^{\mathrm{c}}$ & $22.79 \pm 0.73^{\mathrm{a}}$ & $32.60 \pm 1.31^{\mathrm{b}}$ \\
\hline
\end{tabular}

${ }^{\text {a }}$ Processing parameters were: HTST $72{ }^{\circ} \mathrm{C}$, $15 \mathrm{sec}$; UHT, $140{ }^{\circ} \mathrm{C}, 5 \mathrm{sec}$; high-pressure (HP), 200, 400, 600, $800 \mathrm{MPa}$ for $30 \mathrm{~min}$ at $20{ }^{\circ} \mathrm{C}$. Values are means \pm standard deviation $(\mathrm{n}=3)$; means within a column with different superscript letters are significantly different $(p<0.05)$. 


\section{Table 4}

30 Rennet coagulation time (RCT), the final storage modulus $G^{\prime}$ after $60 \mathrm{~min}$ at $30^{\circ} \mathrm{C}$, and $\mathrm{pH}$ of raw and processed skimmed camel and bovine 31 milk. $^{\text {a }}$

\begin{tabular}{lllll}
\hline Treatment & RCT $(\mathrm{min})$ & Final $G^{\prime}$ value $(\mathrm{Pa})$ & Initial $\mathrm{pH}$ & Final $\mathrm{pH}$ \\
\hline Camel milk & & & & \\
Raw skim milk & $16.16 \pm 1.86^{\mathrm{c}}$ & $8.85 \pm 1.17^{\mathrm{b}}$ & $6.68 \pm 0.03$ & $6.47 \pm 0.19$ \\
HTST & $27.64 \pm 1.46^{\mathrm{b}}$ & $4.04 \pm 0.70^{\mathrm{c}}$ & $6.64 \pm 0.01$ & $6.64 \pm 0.01$ \\
UHT & - & - & $6.65 \pm 0.04$ & $6.63 \pm 0.02$ \\
HP200 & $25.20 \pm 1.41^{\mathrm{b}}$ & $17.86 \pm 1.53^{\mathrm{a}}$ & $6.53 \pm 0.13$ & $6.35 \pm 0.01$ \\
HP400 & $33.84 \pm 0.41^{\mathrm{a}}$ & $3.68 \pm 6.37^{\mathrm{c}}$ & $6.51 \pm 0.00$ & $6.32 \pm 0.01$ \\
HP600 & - & - & $6.56 \pm 0.01$ & $6.32 \pm 0.02$ \\
HP800 & - & $6.71 \pm 0.00$ & $6.58 \pm 0.04$ \\
& & & & \\
Bovine milk & & & & $6.64 \pm 0.15$ \\
Raw skim milk & $31.18 \pm 1.07^{\mathrm{b}}$ & $13.74 \pm 2.82^{\mathrm{ab}}$ & $6.73 \pm 0.14$ & $6.71 \pm 0.03$ \\
HTST & $35.66 \pm 0.46^{\mathrm{a}}$ & $7.44 \pm 2.24^{\mathrm{b}}$ & $6.90 \pm 0.03$ & $6.69 \pm 0.01$ \\
UHT & - & $6.70 \pm 0.01$ & $6.53 \pm 0.17$ \\
HP200 & - & $6.71 \pm 0.03$ & $6.82 \pm 0.04$ \\
HP400 & $22.79 \pm 0.98^{\mathrm{c}}$ & $22.72 \pm 6.92^{\mathrm{a}}$ & $6.42 \pm 0.05$ \\
HP600 & $30.92 \pm 1.86^{\mathrm{b}}$ & $13.41 \pm 4.04^{\mathrm{ab}}$ & $6.87 \pm 0.00$ & $6.66 \pm 0.13$ \\
HP800 & $30.92 \pm 1.86^{\mathrm{b}}$ & $15.41 \pm 2.19^{\mathrm{ab}}$ & $6.42 \pm 0.05$ & $6.83 \pm 0.01$ \\
\hline
\end{tabular}

${ }^{\text {a }}$ Processing parameters were: HTST $72{ }^{\circ} \mathrm{C}, 15 \mathrm{sec}$; UHT, $140{ }^{\circ} \mathrm{C}$, $5 \mathrm{sec}$; high-pressure (HP), 200, 400, 600, $800 \mathrm{MPa}$ for 30 min at $20{ }^{\circ} \mathrm{C}$. Values are means \pm standard deviation ( $\mathrm{n}=3$; -, milk failed to coagulate); means within a column with different superscript letters are significantly different $(p<0.05)$. 

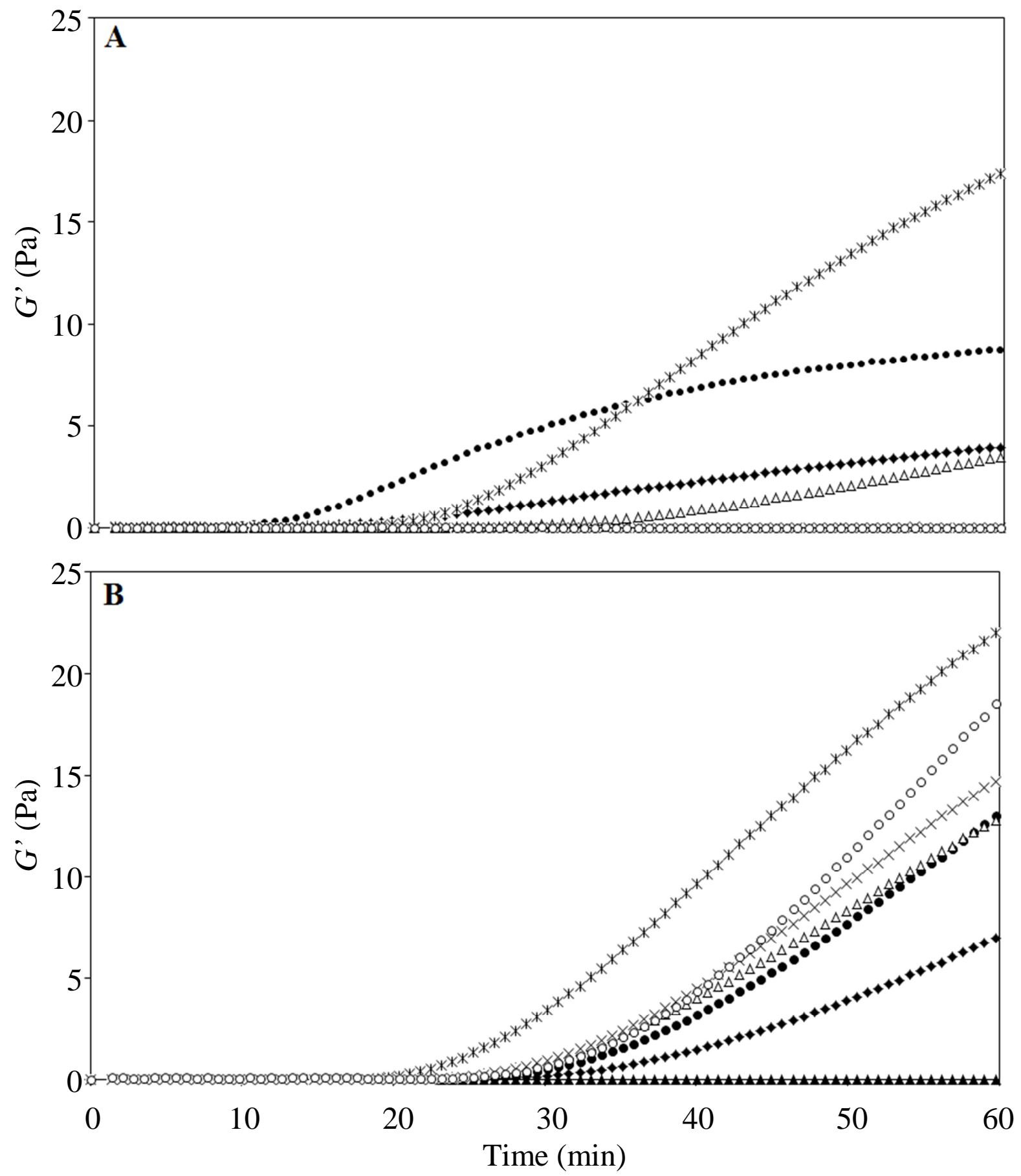

3 4 
Biplot (axes PC1 and PC2: 82.30 \%)

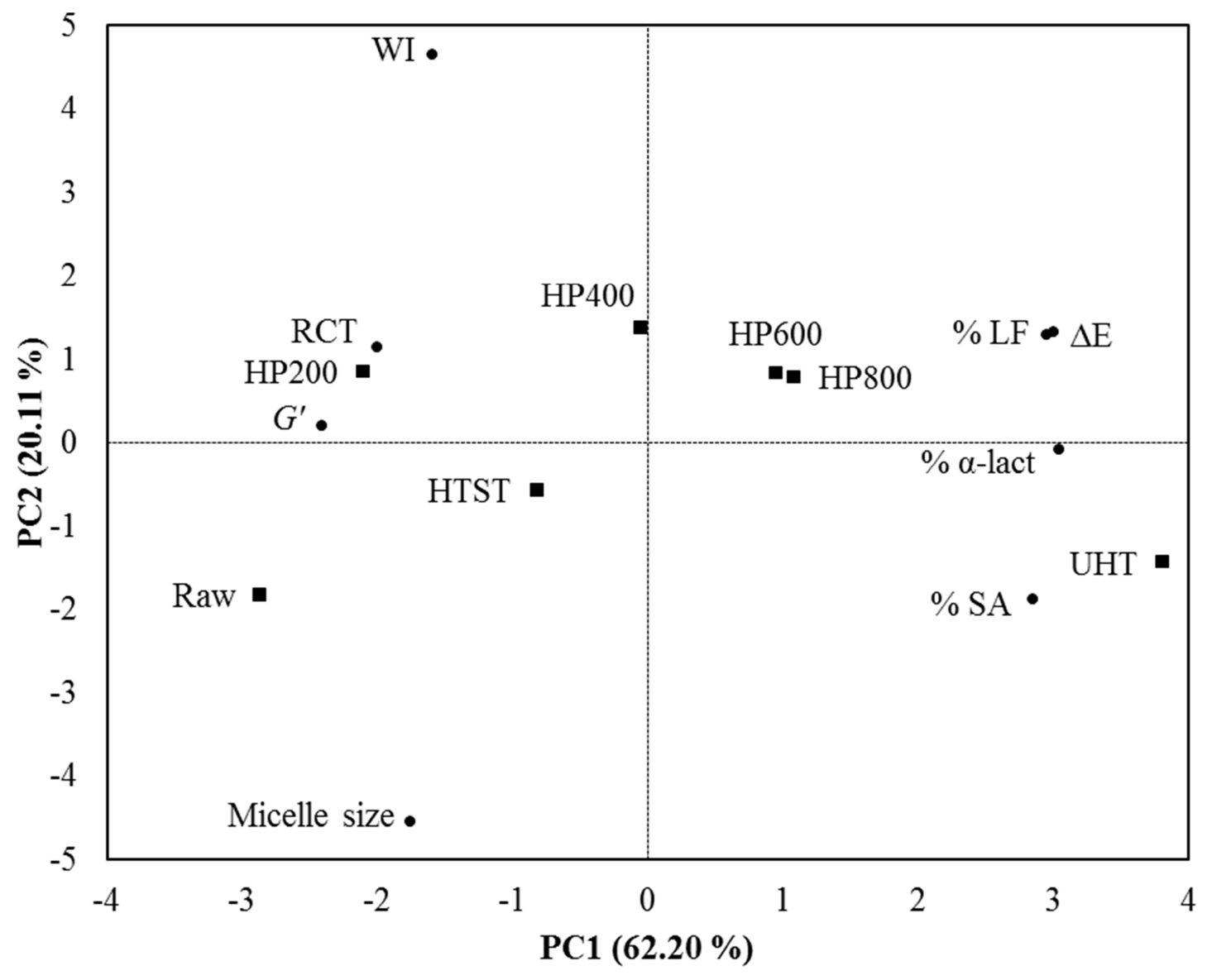

13 